\title{
PENGARUH BEBAN KERJA DAN DISIPLIN KERJA TERHADAP KINERJA KARYAWAN \\ (PADA PT.SEMBILAN PILAR UTAMA) \\ 1); Welly Hartono ${ }^{2)}$; Merta Kusuma \\ 1) Department of Management, Faculty of Economic and Business, Universitas Muhammadiyah Bengkulu \\ 2) Department of Management, Faculty of Economic and Business, Universitas Muhammadiyah Bengkulu \\ Email: ${ }^{1)}$ wellyhartono739@gmail.com; ${ }^{2}$ mertakusuma@umb.ac.id
}

\section{How to Cite :}

Hartono, W. (2020). Pengaruh Beban Kerja dan Disiplin Kerja Terhadap Kinerja Karyawan (Pada PT.Sembilan Pilar Utama)

\section{ARTICLE HISTORY}

Received [28 Juni 2020]

Revised [20 Juli 2020]

Accepted [31 Juli 2020]

\section{KEYWORDS}

Workload and Work Discipline on Employee Performance

This is an open access article under the $C C-B Y-S A$ license

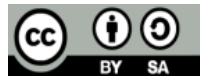

\section{ABSTRAK}

Penelitian ini berjudul pengaruh Beban Kerja dan Disiplin Kerja Terhadap Kinerja Karyawan pada PT. Sembilan Pilar Utama. Rumusan masalah dalam penelitian ini yaitu apakah beban kerja dan disiplin kerja berpengaruh signifikan terhadap kinerja karyawan pada PT. Sembilan Pilar Utama. Tujuan dari penelitian ini adalah Untuk mengetahui pengaruh beban kerja dan disiplin kerja terhadap kinerja karyawan pada Pt. Sembilan Pilar Utama.Penelitian ini dilakukan pada karyawan PT. Sembilan Pilar Utama.Sedangkan waktu penelitian selama 10 hari yakni pada tanggal 17 januari sampai 27 januari 2020.Adapun populasi dari penelitian ini adalah karyawan PT. Sembilan Pilar Utama, sedangkan sempel penelitian ini adalah karyawan PT. Sembilan Pilar Utama yang berjumlah 45 orang, dan menggunakan metode kuantitatif. Dengan teknik analisis data uji penelitian, hasil penelitian dapat disimpulkan bahwa persepsi responden tentang Beban Kerja (X1) Dan Disiplin kerja (X2) berpengaruh terhadap Kinerja Karyawan (Y) dengan hasil regresi linier berganda didapat persamaan sebagai berikut : $\mathrm{Y}=1.802+$ 0.466 (X_1) + 0.516 (X_2) Hasil penelitian dan hipotesis menunjukkan bahwa Beban kerja memiliki nilai yaitu t_hit>t_tabel $(3.658>2.0180)$ dan $(\operatorname{sig}<\alpha=0,001<0,050)$, Disiplin kerja memiliki nilai yaitu $\mathrm{t}$ h hit $>\mathrm{t}$ tabel $(12.192>2.0180)$ dan $(\mathrm{sig}<\alpha=$ $0,000<0,050)$. Secara simultan berpengaruh secara signifikan terhadap kinerja karyawan.Secara parsial ke dua variabel mempunyai pengaruh signifikan terhadap kinerja karyawan.Sebaiknya pimpinan PT. Sembilan Pilar Utama meningkatkan kinerja karyawan agar tercapai suatu tujuan yang diinginkan dalam perusahaan.

\section{ABSTRACT}

This study entitled the effect of Workload and Work Discipline on Employee Performance at PT. Nine Main Pillars. The formulation of the problem in this research is whether the workload and work discipline significantly influence employee performance at PT. Nine 


\begin{abstract}
Main Pillars. The purpose of this study was to determine the effect of workload and work discipline on employee performance at Pt. Nine Main Pillars. This research was conducted on the employees of PT. Nine Main Pillars. While the research time is 10 days, from 17 January to 27 January 2020. The population of this study is the employees of PT. Nine Main Pillars, while the sample of this study are employees of PT. Nine Main Pillars totaling 45 people, and using quantitative methods. With the research test data analysis technique, the results of the study can be concluded that the respondents' perceptions about Workload (X1) and Work Discipline (X2) affect Employee Performance $(Y)$ with the results of multiple linear regression obtained the following equation: $Y=1.802+0.466\left(X \_1\right)$ $+0.516\left(X \_2\right)$. The results of the study and the hypothesis show that workload has a value that is t_hit<t_tabel $(3.658>2.0180)$ dan (sig $<\alpha=0,001<0,050)$, Work discipline has a value that is $t$ hit $>$ t_table $(12.192>2.0180)$ dan $($ sig $<\alpha=0,000<0,050)$. Simultaneously significant effect on employee performance. Partially the two variables have a significant influence on employee performance. We recommend that the leadership of PT. Nine Main Pillars improve employee performance in order to achieve a desired goal in the company.
\end{abstract}

\title{
PENDAHULUAN
}

Manusia merupakan aset utama dalam organisasi, sehingga sumber daya manusia (SDM) harus dikelola dan dimanfaatkan secara seimbang dan manusiawi.Perusahaan memerlukan sumberdaya untuk mencapai tujuannya.Sumber daya yang dibutuhkan itu, salah satunya adalah sumberdaya manusia.Dengan perkembangan zaman yang semakin maju, karyawan harus bisa menyesuaikan diri dalam segala kondisi.Beban kerja yang semakin berat, banyaknya kebutuhan yang ingin dipenuhi, tingkat pendapatan yang tidak sesuai dengan biaya hidup, persaingan yang semakin ketat dan seterusnya dapat menjadi ancaman untuk tetap dapat bertahan hidup.Sumber Daya Manusia (SDM) merupakan salah satu hal yang memliki peranan terpenting.SDM dalam organisasi berperan dalam membentuk suatu perencanaan, realisasi dalam kegiatan, dan evaluasi untuk mencapai hasil yang lebih baik dikemudian hari, pengambilan keputusan merupakan keahlian, kemampuan, dan dasar ilmu pengetahuan yang memadai.Didalam organisasi diperlukan sebuah pembinaan yang baik bagi para pegawainya, untuk mencegah terjadinya pelanggaran yang dapat mengakibatkan kerugian bagi perusahaan

Beban kerja dapat diartikan sebagai berikut : Secara umum, istilah beban kerja mengacu pada jumlah pekerjaan yang dialokasikan kepada pegawai untuk diselesaikan (Wefald, et.al., 2008:16). Beban kerja menurut Tarwaka (2011:106) adalah suatu kondisi dari pekerjaan dengan uraian tugasnya harus diselesaikan pada batas waktu tertentu.

Disiplin kerja merupakan salah satu faktor yang memegang peranan penting dalam pencapaian tujuan.Mengingat begitu pentingnya peranan disiplin kerja bagi para karyawan, diharapkan para karyawan harus selalu berupaya untuk menjaga dan meningkatkan disiplin kerja.Untuk mendapatkan hasil kerja dapat tercapai secara maksimal maka pegawai harus mempunyai kinerja yang baik.Kinerja yang baik, hasil yang didapatkan juga baik. Dengan disiplin yang tinggi para pegawai akan menaati semua peraturan yang ada di perusahaan, sehingga pelaksanaan pekerjaan dapat berjalan sesuai dengan target yang ditentukan oleh organisasi. Menurut Devis (2002) mendefinisikan bahwa disiplin adalah tindakan manajemen untuk memberikan semangat kepada pelaksanaan standar organisasi, ini adalah pelatihan yang mengarah pada upaya membenarkan dan melibatkan pengetahuan-pengetahuan sikap dan 
perilaku pegawai sehingga ada kemauan pada diri pegawai untuk menuju pada kerjasama dan prestasi yang lebih baik. Hal ini juga sesuai dengan pendapat HadadNawawi (1998) yang menyatakan bahwa disiplin adalah usaha untuk mencegah terjadinyapelanggran-pelanggaran terhadap ketentuan yang telah disetujui bersama dalam melaksanakan kegiatan agar pembinaan hukuman pada seseorang atau kelompok dapat dihindari. Sedangkan, Malayu S.P. Hasibuan (2003) menyatakan bahwa kedisiplinan adalah kesadaran dan kesediaan seseorang dalam menaati semua peraturan perusahaan dan norma-norma yang berlaku

Kinerja karyawan dalam organisasi mengarah kepada kemampuan karyawan dalam melaksanakan keseluruhan tugas-tugas yang menjadi tanggung jawabnya. Tugas-tugas tersebut biasanya berdasarkan indikator-indikator keberhasilan yang sudah ditetapkan dan sebagai hasilnya akan diketahui jika seseorang pegawai masuk dalam tingkat kinerja tertentu (Ardiana et al, 2014).

Tugas-tugas yang menjadi tanggung jawab setiap individu karyawanlah yang dianggap sebagai pekerjaan yang diterima, dan pekerjaan yang diterima secara banyak dengan tenggat waktu yang tetap sama maka akan adanya beban atau sering disebut beban kerja bagi para karyawan. Menurut Wibowo (2010;7) Kinerja adalah tentang melakukan pekerjaan dan hasil yang dicapai dari pekerjaan tersebut. Suatu kinerja yang menurun itu di karenakan tingginya target suatu perusahaan, sehingga karyawan merasa terbebani dan melemahnya kinerja karyawan.

PT. Sembilan Pilar Utama adalah perusahaan yang bergerak dibidang AMDK (air minum dalam kemasan). pada saat ini PT. Sembilan Pilar Utama sudah mempunyai 2 merk yaitu MAS dan OK MAS. Jenis produk yang dikeluarkan yaitu, berbentuk cap 150ml, 220ml, 240ml, Botol 330ml,600ml, 1500ml, dan Galon 19L.

Permasalahan yang ada di PT. Sembilan Pilar Utama terletak pada kinerja karyawan yang menurun, karena karyawan sering tidak bisa mencapai target yang di tentukan oleh perusahaan. Berdasarkan data 4 tahun terakhir dan dilampirkan 3 tahun belakang adalah data produksi pada tahun 2016-2018 di Pt. Sembilan Pilar Utama. Berikut adalah tabel hasil produksi air minum dalam kemasan bermerek MAS di PT. Sembilan Pilar Utama.

Bukan hanya pada bagian produksi saja yang terdapat permasalahannya, tetapi terdapat juga pada bagian sopir pengangkut barang produksi, ini terjadi dikarenakan mereka harus mengejar target, dan sopir juga tidak memiliki jam kerja, merka harus stanby 24 jam. Apalagi di saat jam malam, belum lagi kendala di perjalanan dan fisik tubuh yang mungkin sudah lelah dan tidak kondusif untuk melakukan perjalan. Diposisi inilah sopir terasa terbebani dalam menjalankan pekerjaannya.

Dari segi disiplin terdapat beberapa indikasi kinerja yang belum optimal. Misalnya, masih adanya pegawai yang datang terlambat, penyelesaian tugas yang memakan waktu yang lebih lama dari waktu yang ditentukan,masih adanya karyawan yang tidak hadir tanpa keterangan serta meninggalkan tugas disaat jam kerja. Dari penjelasan diatas dapat ditarik kesimpulan bahwa disiplin memang sangat diperlukan bagi sebuah perusahaan, tidak terkecuali PT. Sembilan Pilar Utama.

\section{LANDASAN TEORI}

\section{Kinerja}

Kinerja berasal dari kata job Performance atau Actual Perfomance (prestasi kerja atau prestasi sesungguhnya yang di capai oleh seseorang). Menurut Sedarmayanti (2010:176), kinerja merupakan hasil kerja seseorang, dimana keseluruhan hasil tersebut dapat dibuktikan secara konkrit dan dapat diukur.

Menurut (Sedarmayanti, 2010:263) Beberapa indikator kinerja karyawan yang digunakan dalam penelitian ini adalah sebagai berikut: 
1. Prestasi kerja, yaitu kemampuan yang dimiliki karyawan dalam penyelesaian tugas yang telah ditargetkan.

2. Tanggung jawab, yaitu karyawan memiliki rasa tanggung jawab untuk menyelesaikan tugasnya dengan baik.

3. Kejujuran, yaitu penyampaian sesuatu yang sesuai dengan keadaan yang sebenarnya.

4. Kerja sama, yaitu kemampuan karyawan dalam bekerja sama dengan rekan sekerjanya.

5. Inisiatif, yaitu kemampuan karyawan dalam menyelesaikan tugas dan pekerjaan serta mampu mengambil keputusan dalam keadaan mendesak.

6. Kecepatan dan ketepatan kerja, yaitu seberapa cepat karyawan mampu menyelesaikan pekerjaan rutin tanpa mengurangi kualitas kerja sesuai dengan waktu yang sditetapkan sebelumnya.

7. Tingkat kesalahan kerja, yaitu kemampuan karyawan dalam menyelesaikan pekerjaan dengan baik tanpa adanya kesalahan.

\section{Beban Kerja}

Beban kerja adalah sekumpulan atau sejumlah kegiatan yang harus diselesaikan oleh suatu unit organisasi atau pemegang jabatan dalam jangka waktu tertentu Sunarso (2010).Permendagri No. 12/2008 menyatakan bahwa beban kerja adalah besaran pekerjaan yang harus dipikul oleh suatu jabatan/unit organisasi dan merupakan hasil kali antara volume kerja dan norma waktu. Jika kemampuan pekerja lebih tinggi dari padatun tutan pekerjaan,akan muncul perasaan bosan. Namun sebaliknya,jika kemampuan pekerja lebih rendah dari pada tuntutan pekerjaan,maka akan muncul kelelahan yang lebih. Beban kerja yang dibebankan kepada karyawan dapat dikategorikan kedalam tiga kondisi, yaitu bebankerja yang sesuai standar, beban kerja yang terlalu tinggi (over capacity) dan beban kerja yang terlalu rendah(under capacity).

Menurut Putra (2012) ada 4 indikator dalam beban kerja yaitu:

1. Target yang Harus Dicapai : Pandangan individu mengenai besarnya target kerja yang diberikan untuk menyelesaikan pekerjaannya. Pandangan mengenai hasil kerja yang harus diselesaikan dalam jangka waktu tertentu.

2. Kondisi Pekerjaan : Mencakup tentang bagaimana pandangan yang dimiliki oleh individu mengenai kondisi pekerjaannya, misalnya mengambil keputusan dengan cepat pada saat pengerjaan barang, serta mengatasi kejadian yang tak terduga seperti melakukan pekerjaan ekstra diluar waktu yang telah ditentukan.

3. Penggunaan Waktu : Kerja Waktu yang digunakan dalam kegiatan-kegiatan yang langsung berhubungan dengan produksi (waktu lingkaran, atau waktu baku atau dasar).

4. Standar Pekerjaan : Kesan yang dimiliki oleh individu mengenai pekerjaannya, misalnya perasaan yang timbul mengenai beban kerja yang harus diselesaikan dalam jangka waktu tertentu.

\section{Disiplin Kerja}

Hasibuan (2012) argues that discipline is the awareness and willingness of a person to obey all the rules of the institution and the prevailing social norms. Bermakna bahwa disiplin adalah kesadasran dan kemauan seseorang untuk mematuhi semua itu aturan institusi dan norma social yang berlaku.Tingkat disiplin kerja seorang karyawan dalam suatu perusahan dapat diketahui melalui indikato-indikator disiplin kerja.Pada dasarnya banyak sekali faktor yang dapat dijadikan sebagai indikator disiplin kerja karyawan misalnya seperti yang di kemukakan oleh Hasibuan (2006: 194-198):

1. Frekuensi kehadiran

Frekuensi kehadiran adalah tingkat kehadiran karyawan setiap harinya di dalam perusahaan.

Frekuensi kehadiran dapat diarikan pula dimana karyawan selalu datang dan pulang tepat pada waktunya. 
2. Tujuan dan kemampuan

Tujuan (pekerjaan) yang akan dicapai harus realistis dan ditetapkan dengan jelas, serta dapat mengembangkan kreativitas karyawan. Dengan kata lain tujuan (pekerjaan) yang di berikan kepada karyawan harus sesuai dengan kemampuan karyawan tersebut, sehingga dia akan melakukan pekerjaan tersebut dengan sungguh-sungguh.

3. Keteladanan pemimpin

Pemimpin dapat menjadi faktor yang menentukan kedisiplinan karyawannya, karena seoeang pemimpin biasanya dijadikan teladan dan panutan oleh para karyawan. Pemimpin harus memberikan contoh yang baik kepada para karyawan, seperti berprilaku jujur, adil, serta berdisiplin. Pemimpin jangan mengharapkan para karyawannya berdisiplin jika iua sendiri kurang berdisiplin. Pemimpin harus menyadari bahwa perilaku dan perbuatannya akan dicontoh dan di teladani oleh para karyawan. Oleh karena itu seorang pemimpin harus mempunyai prilaku serta kedisiplinan yang baik, dengan harapan akan dicontoh dan diikuti oleh para kaeryawan.

4. Sanksi dan ketegasan

sanksi adalah salah satu cara yang dilakukan dalam memelihara kedisiplinan karyawan. Dengan adanya sanksi harus ditetapkan berdasarkan pertimbangan logis, masuk akal, dan informasikan secara jelas kepada semua karyawan. Sanksi hendaknya disesuaikan dengan pelanggaran yang dilakukan oleh karyawan, bersifat mendidik, dan menjadi suatu alat untuk menjaga kedisiplinan suatu perusahaan. Ketegasan pemimpin dalam melakukan tindakan akan mempengaruhi kedisiplinan karyawan. Pemimpin harus tegas dalam melakukan tindakan serta harus berani untuk menghukum setiap karyawan yang berprilaku indisipliner sesuai dengan sanksi yang berlaku. Pimpinan yang bertindak tegas menerapkan sanksi kepada karyawan yang indispliner akan disegani dan diakui kepemimpinannya oleh karyawan, sehingga pimpinan akan dapat memelihara kedisiplinan karyawannya.

5. Keadilan

Pada dasarnya dalam sifat manusia terdapat ego yang merasa dirinya penting dan ingin diperlakukan sama dengan manusia lainnya. Atas dasar tersebut maka seorang pemimpin harus bersikap adil kepada para karyawan. Balas jasa ataupun sanksi yang diberikan akan merangsang terciptanya kedisiplinan karyawan yang baik apabila didasari dengan keadilan. Dengan keadilan baik akan menciptakan kedisiplinan yang baik pula.

6. Hubungan kemanusiaan

Hubungan kemanusiaan yang harmonis diantara sesama karyawan ikut menunjang dalam menciptakan kedisiplinan yang baik dan suasana kerja yang nyaman pada suatu perusahaan. Hubungan-hubungan tersebut dapat bersifat vertikal maupun horizontal. Pimpinan harus berusaha menciptakan suasana hubungan kemanusiaan yang serasi serta mengikat, vertikal , auoun horizontal diantara sesama karyawan. Hal ini akan memotivasi kedisiplinan yang baik dalam perusahaan.

7. Balas jasa

Balas jasa berperan serta dalam mempengaruhi kedisiplinan karyawan karena balas jasa akan memberikan kepuasan dan kcintaan karyawan terhadap perusahaan/pekerjaan. Untuk mewujudkan kedisiplinan yang baik, perusahaan harus mampu memberikan balas jasa yang sesuai kepada karyawan. Kedisiplinan karyawan tidak mungkin baik apabila balas jasa yang mereka terima dari perusahaan tidak sesuai atau abahkan kurang memuaskan untuk memenuhi kebutuhan hidupnya. 


\section{METODE PENELITIAN}

\section{Metode Analisis}

Penelitian ini dilaksanakan di PT. Sembilan Pilar Utama. Waktu penelitian pada bulan Desember tahun 2019 sampai dengan selesai .Jenis penelitian ini dikategorikan sebagai explanatory research yaitu penelitian yang bertujuan menjelaskan hubungan kausal antara variabel-variabel melalui pengujian hipotesis. Metode penelitian yang akan dilakukan ialah penelitian kuantitatif.Penelitian ini menggunakan seluruh anggota populasinya disebut sampel total (total sampling).

\section{Pembahasan}

\section{HASIL DAN PEMBAHASAN}

Pada uji validitas instrumen yang akan dilakukan pada setiap instrumen penelitian memperoleh hasil jika $r$ positif, serta $r \quad 0,30$ maka pernyataan tersebut valid, dan jika $r<0,30$ maka item pernyataan tidak valid (Sugiyono 2013). Dapat dilihat pada tabel 4.7 Dari setiap item pernyataan

Tabel 1

Ringkasan Hasil uji Instrumen variabel Beban Kerja dan disiplin kerja Terhadap kinerja Karyawan

\begin{tabular}{|c|c|c|c|}
\hline Varibael & $\begin{array}{c}\text { No. } \\
\text { Pernyat } \\
\text { aan }\end{array}$ & $\begin{array}{c}\text { Total } \\
\text { pearson } \\
\text { correlation }\end{array}$ & $\begin{array}{l}\text { Ketera } \\
\text { ngan }\end{array}$ \\
\hline \multirow{4}{*}{ Beban Kerja $\left(\mathbf{X}_{1}\right)$} & 1 & 0,606 & Valid \\
\hline & 2 & 0,516 & Valid \\
\hline & 3 & 0,416 & Valid \\
\hline & 4 & 0,578 & Valid \\
\hline \multirow{11}{*}{ Disiplin Kerja $\left(\mathbf{X}_{2}\right)$} & 1 & 0,594 & Valid \\
\hline & 2 & 0,527 & Valid \\
\hline & 3 & 0,569 & Valid \\
\hline & 4 & 0,507 & Valid \\
\hline & 5 & 0,459 & Valid \\
\hline & 6 & 0,455 & Valid \\
\hline & 7 & 0,450 & Valid \\
\hline & 8 & 0,414 & Valid \\
\hline & 9 & 0,542 & Valid \\
\hline & 10 & 0,484 & Valid \\
\hline & 11 & 0,526 & Valid \\
\hline \multirow{7}{*}{ Kinerja karyawan (Y) } & 1 & 0,851 & Valid \\
\hline & 2 & 0,525 & Valid \\
\hline & 3 & 0,530 & Valid \\
\hline & 4 & 0,851 & Valid \\
\hline & 5 & 0,438 & Valid \\
\hline & 6 & 0,331 & Valid \\
\hline & 7 & 0,446 & Valid \\
\hline
\end{tabular}

\section{Sumber : Hasil Penelitian Dan Data Diolah}

Berdasarkan tabel diatas hasil uji validitas dapat dilihat bahwa $\mathrm{R}$ hitung lebih besar dari r yaitu lebih besar dari 0,30. Maka dari 20 pernyataanyang di uji semua item valid. 
Tabel 2. Ringkasan Hasil Nilai Cronbach Alpa Dari Tipa Variabel

\begin{tabular}{|l|l|c|c|r|}
\hline Variabel & $\begin{array}{l}\text { Nilai cronbach } \\
\text { alpa }\end{array}$ & Cut of value & $\begin{array}{l}\text { Jumlah } \\
\text { pernyataan }\end{array}$ & Keterangan \\
\hline Beban Kerja & 0,658 & 0,60 & 4 & Reliabel \\
\hline Disiplin Kerja & 0,720 & 0,60 & 11 & Reliabel \\
\hline Kinerja karyawan & 0,733 & 0,60 & 7 & Reliabel \\
\hline
\end{tabular}

\section{Sumber : Hasil Penelitian Dan Data Diolah}

Dari tabel diatas terlihat bahwa semua variabel memiliki nilai cronbach alpa lebih besar dari 0,60 maka dapat disimpulkan bahwa semua variabel ini reliabilitas.

Tabel 3

Uji multikolinieritas antara Beban Kerja $\left(\mathrm{X}_{1}\right)$ dan Disiplin Kerja $\left(\mathrm{X}_{2}\right)$ dengan variabel KeKinerja Karyawan (Y)

\begin{tabular}{|l|l|l|l|l|}
\hline No & Variabel & Tolerance & & VIF \\
\hline 1 & Beban Kerja & 0.882 & 1.134 & Non Multikolinieritas \\
\hline 2 & Disiplin Kerja & 0.882 & 1.134 & Non Multikolinieritas \\
\hline
\end{tabular}

\section{Sumber Penelitian 2020}

Berdasarkan Tabel diatas terlihat bahwa semua variabel mempunyai nilai toleransi diatas 0,1 dan nilai VIF dibawah 10, dengan demikian dapat disimpulkan bahwa variabel pada penelitian ini bebas multikolinieritas.

Analisis regresi linear berganda yang akan dibahas dalam penelitian ini sehingga penulis bisa menggambarkan mengenai tanggapan responden (Beban Kerja dan Disiplin Kerja) terhadap Kinerja Karyawanpada Pada PT. Sembilan Pilar Utama. Berdasarkan estemasi regresi linier berganda dengan menggunakan program SPSS Versi 24,0 For Windows, maka diperoleh tabel dibawah ini :

Tabel 4. Hasil Analisis Regresi Linear Berganda

\section{Coefficients $^{\mathbf{a}}$}

\begin{tabular}{|c|c|c|c|c|c|}
\hline \multirow[b]{2}{*}{ Model } & \multicolumn{2}{|c|}{ Unstandardized Coefficients } & \multirow{2}{*}{\begin{tabular}{|c|}
$\begin{array}{l}\text { Standardized } \\
\text { Coefficients }\end{array}$ \\
Beta
\end{tabular}} & \multirow[b]{2}{*}{$\mathrm{t}$} & \multirow[b]{2}{*}{ Sig. } \\
\hline & $\mathrm{B}$ & Std. Error & & & \\
\hline 1 (Constant) & 1.802 & 2.240 & & .804 & .426 \\
\hline Beban kerja & .466 & .128 & .242 & 3.658 & .001 \\
\hline Disiplin kerja & .516 & .042 & .806 & 12.192 & .000 \\
\hline
\end{tabular}

a. Dependent Variable: Kinerja

\section{Sumber: Output SPSS 24,0}

Dari perhitungan hasil diatas didapatkan persamaan regresinya adalah sebagai berikut :

$\mathrm{Y}=1.802+0.466(\quad)+0.516(\quad)$

Untuk mengetahui besarnya presentase sumbangan pengaruh variabel bebas Beban Kerja ( ) dan Disiplin Kerja ( ) terhadap variabel terikat Kinerja Karyawan (Y) maka dari perhitungan komputer menggunakan SPSS 24,0 didapatkan uji koefisien determinasi dapat dilihat pada table sebagai berikut: 
Tabel 5

Nilai Koefisien Determinasi ( )

\begin{tabular}{|c|c|c|c|c|}
\hline Model & $\mathrm{R}$ & R Square & $\begin{array}{l}\text { Adjusted R } \\
\text { Square }\end{array}$ & Std. Error of the Estimate \\
\hline & $914^{\mathrm{a}}$ & .836 & .828 & 1.53222 \\
\hline
\end{tabular}

a. Predictors: (Constant), Disiplin kerja, Beban kerja

\section{Sumber: Output SPSS 24,0 (lampiran 5)}

Berdasarkan tabel diatas dapat diketahui nilai koefisien determinasi Adjusted ( ) diperoleh nilai sebesar 0.828. Nilai ini mempunyai arti bahwa variabel Beban Kerja dan Disiplin Kerja terhadap variabel Kinerja Karyawan memberikan sumbangan sebesar 0.828 atau $82.8 \%$ terhadap Kinerja Karyawan pada Pada PT. Sembilan Pilar Utama sedangkan sisanya sebesar 0.164 atau $16.4 \%$ dipengaruhi oleh variabel lain yang tidak masuk dalam model penelitian ini.

\section{Tabel 6}

\section{Hasil Pengujian Hipotesis dengan Uji t}

\section{Coefficients $^{\mathrm{a}}$}

\begin{tabular}{|c|r|r|r|r|r|}
\hline & \multicolumn{2}{|l|}{} & \multicolumn{2}{l|}{$\begin{array}{l}\text { Standardized } \\
\text { Unstandardized Coefficients }\end{array}$} & \\
\cline { 2 - 4 } Model & \multicolumn{1}{|c|}{ B } & Std. Error & \multicolumn{1}{c|}{ Beta } & \multicolumn{1}{c|}{$\mathrm{t}$} \\
\hline 1 (Constant) & 1.802 & 2.240 & & .804 & .426 \\
Beban kerja & .466 & .128 & .242 & 3.658 & .001 \\
Disiplin kerja & .516 & .042 & .806 & 12.192 & .000 \\
\hline
\end{tabular}

a. Dependent Variable: Kinerja

Sumber: Output SPSS 24.0

Untuk menguji pengaruhh variabel bebas secara parsial terhadap variabel terikat digunakan uji $\mathrm{F}$ sebagai berikut :

Tabel 7

ANOVA $^{b}$

Hasil Pengujian Hipotesis dengan Uji F

\begin{tabular}{|r|r|r|r|r|r|}
\hline Model & Sum of Squares & Df & Mean Square & F & Sig. \\
\hline 1 Regression & 503.707 & 2 & 251.854 & 107.276 & .000 \\
Residual & 98.604 & 42 & 2.348 & & \\
Total & 602.311 & 44 & & & \\
\hline
\end{tabular}

a. Predictors: (Constant), Disiplin kerja, Beban kerja

b. Dependent Variable: Kinerja

\section{Sumber: Output SPSS 24,0}

Berdasarkan tabel uji hipotesis dengan uji $\mathrm{F}$ diperoleh sebesar 107.276 dengan nilai sebesar 4.0726 yaitu $(107.276>4.0726)$ dan ( $\mathrm{sig}<=0.000<0,050)$, maka dengan demikian dapat disimpulkan bahwa diterima artinya secara simultan variabel Beban Kerja dan Disiplin Kerja berpengaruh signifikan terhadap Kinerja Karyawan di Pada PT. Sembilan Pilar Utama. 
Berdasarkan hasil penelitian dan pengolahan data mentah yang dilakukan pada Pada PT. Sembilan Pilar Utama melalui penyebaran kuesioner terhadap 45 orang responden yang telah diuji sehingga dapat diketahui pengaruh Beban Kerja dan Disiplin KerjaTerhadap Kinerja Karyawanpada Pada PT. Sembilan Pilar Utama.

1. Pengaruh Beban Kerja ( )Terhadap Kinerja Karyawan(Y)

Berdasarkan uji yang telah dilaksanakan menunjukkan bahwa Beban Kerja terhadap Kinerja Karyawanberadapadadaerahpositifdansignifkan.maka $\mathrm{H}_{1}$ dalam penelitian ini dapat diterima. Beban kerja merupakan faktor ekstrinsik individu yang menjadi salah satu sumber munculnya salah satu permasalahan kinerja, karena beban kerja yang dihadapinya terlalu tinggi. Kondisi ini menuntut karyawan untuk memberikan energi yang lebih besar dari pada biasanya dalam menyelesaikan pekerjaannya, tidak semua karyawan memiliki tingkat ketahanan terhadap tekanan dari beban kerja yang sama, tetapi semua ini tergantung pada masing-masing individualnya, maksudnya tugas-tugas tersebut akan selesai dengan baik atau tidak tergantung bagai mana seseorang menghayati beban kerja yang di rasakannya.

Berdasarkan hasil penelitian terdahulu yang dilakukan oleng Anggit Astianto dalam jurnal ilmu dan riset Manajemen volume.3 No 7 tahun 2014 mengatakan bahwa secara simultan stres kerja dan beban kerja berpengaruh signifikan terhadap kinerja karyawan PDAM surabaya. Selain itu penelitian yang dilakukan oleh Agripa Toar Sitepu dalam jurna MBA vol.1 No.4 tahun 2013 juga menyatakan hal yang sama bahwa beban kerja dan motivasi secara bersama-sama berpengaruh terhadap kinerja karyawan PT. Bank Tabungan Nengara TBK cabang Manado.

2. Pengaruh Beban KerjaKerja( )Terhadap Kinerja Karyawan(Y)

Dalam penelitian ini Disiplin Kerja memiliki pengaruh signifikan terhadap Kinerja Karyawan PT. Sembilan Pilar Utama. maka dalam penelitian ini dapat diterima. Terbukti dari teori Nawawi (2012:97), menyatakan bahwa keefektifan suatu organisasi hanya dapat diwujudkan dengan diwujudkannya disiplin kerja yang tinggi. Disiplin kerja merupakan kondisi organisasi atau iklim kerja yang sangat penting dalam kepemimpinan untuk mengefektifkan organisasi. Tanpa disiplin kerja akan sangat sulit mewujudkan efektivitas dan efisiensi kerja sehingga akan sulit pula dalam mencapai tujuan organisasi secara maksimal. Dan didukung oleh penelitian terdahulu Rima Dwining tyas, Bambang Swasto Sunuharyo (2018).

3. Pengaruh Beban Kerja $\left(\mathrm{X}_{1}\right)$ dan Disiplin Kerja $\left(\mathrm{X}_{2}\right)$ terhadap Kinerja Karyawan

Beban Kerja dan Disiplin Kerja memiliki pengaruh terhadap Kinerja Karyawan (Y), dapat disimpulkan bahwa diterima artinya secara bersamaan variabel Beban Kerja ( ) dan Disiplin Kerja ( ) memiliki pengaruh yang signifikan terhadap Kinerja Karyawan (Y) di Pada PT. Sembilan Pilar Utama.

\section{KESIMPULAN DAN SARAN}

\section{Kesimpulan}

Berdasarkan hasil penelitian yang telah dilakukan tentang pengaruh Beban Kerja dan Disiplin Kerja Terhadap Kinerja Karyawan pada Pada Pt. Sembilan Pilar Utama, dapat disimpulkan sebagai berikut :

1. Beban Kerja berpengaruh signifikan terhadap Kinerja Karyawan pada Pada PT. Sembilan Pilar Utama. 
2. Disiplin Kerjaberpengaruh signifikan terhadap Kinerja Karyawanpada Pada Pt. Sembilan Pilar Utama.

3. Beban Kerja ( ) dan Disiplin Kerja ( ) secara bersama-sama berpengaruh secara signifikan terhadap Kinerja Karyawan (Y) pada Pada PT. Sembilan Pilar Utama, Ini berarti ditolak dan diterima.

4. Berdasarkan uji koefisien determinasi $\left(\mathrm{R}^{2}\right)\left(\mathrm{X}_{1}\right)$ dan $\left(\mathrm{X}_{2}\right)$ mempunyai pengaruh yang besar terhadap kinerja karyawan.

\section{Saran}

Berdasarkan hasil penelitian, pembahasan dan kesimpulan yang diperoleh, maka saran yang dapat diberikan sebagai berikut :

1. Hasil penelitian menunjukan adanya pengaruh yang signifikan antara variabel Beban Kerja ( ) terhadap Kinerja Karyawan (Y) Pada Pada PT. Sembilan Pilar Utama, variabel Beban Kerja memiliki rata-rata terendah yaitu 3.91 (Waktu untuk mengerjakan pekerjaan saya sudah cukup). Disarankan untuk lebih mengerjakan pekerjakan semaksimal mungkin, agar dapat meningkatkan Kinerja Karyawan pada Pada PT. Sembilan Pilar Utama.

2. Hasil penelitian terlihat bahwa pada variabel Disiplin Kerja memiliki tanggapan responden yang terendah yaitu 3.44 (Karyawan yang tidak menaati peraturan perusahaan dan melakukan kesalahan akan dikenakan sanksi tanpa membeda-bedakan). Disarankan untuk karyawan agar lebih taat terhadap peraturan perusahaan agar bisa mencapai hasil yang memuaskan pada PT. Sembilan Pilar Utama.

3. Hasil penelitian terlihat bahwa pada variabel Beban Kerja, dan Disiplin Kerja memiliki tanggapan responden yang terendah yaitu 3,91 dan 3.44. Disarankan untuk lebih mengerjakan pekerjaan semaksimal mungkin dan lebih taat terhadap peraturan perusahaan agar dapat meningkatkan kinerja karyawan dan hasil yang memuaskan pada PT. Sembilan Pilar Utama.

4. Disarankan bagi peneliti selanjutnya khususnya penelitian yang sama perlu dipertimbangkan untuk faktor-faktor lain diluar variabel Beban Kerja dan Disiplin Kerja terhadap Kinerja Karyawan serta dapat meningkatkan kinerja pada perusahaan

\section{DAFTAR PUSTAKA}

AgripaToarSitepu, 2013. "Beban Kerja dan Motivasi Pengaruhnya Terhadap Kinerja Karyawan pada PT. Bank Tabungan Negara Tbk Cabang Manado”, Jurnal EMBA. Vol.1 No.4, Hal. 1123-1133.

Ardiana, IDKR.,Brahmayanti, L. A., \&Subaedi. (2010). Kompetensi SDM UKM dan Pengaruhnya Terhadap Kinerja UKM di Surabaya.Jurnal Manajemen dan Kewirausahaan. Vol. 12.

Hasibuan, Malayu. 2003. Manajemen sumber daya manusia. PTBumi Aksara. Jakarta.

Merta Kusuma, Nitisimit, Alek. S (2000). Manajemen Personalia dan Sumber Daya Manusia, Ghalia Indonesia : Medan.

Nawawi, Hadari. 2012. Metode Penelitian Bidang Sosial. Yogyakarta: Gajah Mada University Press.

Rivai, Veithzal dan Basri. 2005. Performance Appraisal: sistem yang tepat untuk menilai kinerja karyawan dan meningkatkan daya saing perusahaan. PT. RAJAGRAFINDO PERSADA. Jakarta.

Sugiyono. 2010. Metode Penelitian Pendidikan Pendekatan Kuantitatif, kualitatif, dan R\&D. Bandung: Alfabeta.

Wibowo.(2010). Manajemen Kinerja, Edisi Ketiga. Rajawali Pers,Jakarta. 